\section{Large-Scale Projects in the Amazon: Engaging Social Actors to Promote Sustainable Development}

\author{
Grandes Obras na Amazônia: Engajando Atores Sociais para Promover o \\ Desenvolvimento Sustentável
}

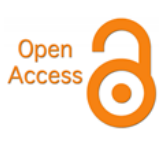

Thomaz Wood Jr.' ${ }^{\circ}$ Dafne Oliveira Carlos de Morais ${ }^{2}$
On March 29, 2017, Daniela Gomes Pinto, Hector Gomez Ang and the other members of the 'Large-Scale Projects in the Amazon — Lessons Learned and Guidelines' project met to disclose the result of 18 months of intense work. The project was created with the aim of helping resolve one of the paradoxes that characterize the Amazon region: it is one of the richest regions in the world in terms of its biodiversity and natural resources but also one of the poorest in Brazil in terms of its economic and social development.

During this period, the team, comprising 17 professionals from the Center for Sustainability Studies at Fundação Getulio Vargas (FGVces) and from the International Finance Corporation (IFC), spoke to dozens of stakeholders: large engineering and construction companies, social organizations, government agencies, representatives of quilombolas (descendants of runaway slaves living in remote communities), riverside populations, and indigenous peoples. The objective was to organize and provide evidence of the lessons learned and the recommendations made in connection with the public policies and business practices that would establish a new type of relationship between large developments and the territories in which they are located.

In an auditorium in the Radisson Hotel in Belém, Daniela, from FGVces, and Hector, from the IFC, talk optimistically about the project's achievements and successes. While waiting to start the closing event of the final phase of the project, they recall how arduous the process of engaging social actors with such dissonant interests was. Daniela reflects on the long months of work and the dilemmas faced by the project. She assesses whether the social technology they used for engaging stakeholders will have been enough to guarantee the successful implementation of the guidelines and what can still be done to help achieve this goal. Success in introducing the guidelines can be a game changer for sustainable development in the Amazon and has a strong impact on local populations and the ecological balance of the region, with repercussions that are felt far beyond Brazil. How to ensure this success is the challenge.

\footnotetext{
1. Fundação Getulio Vargas, Escola de Administração de Empresas de São Paulo (FGV EAESP), São Paulo, SP, Brazil.

2. Centro Universitário FEl, São Paulo, SP, Brazil.
}

Cite as: Wood, T., Jr., \& Morais, D. O. C. (2021). Large-scale projects in the Amazon: Engaging social actors to promote sustainable development. Revista de Administração Contemporânea, 25(3), e200053. https://doi.org/10.1590/1982-7849rac2021200053.en

\# of invited reviewers until the decision:

\# of invited reviewers until the decisio
$1^{\text {st }}$ round
$2^{\text {nd }}$ round
$3^{\text {rd }}$ round
$4^{\text {th }}$ round

JEL Code: Q01, N6, F64. Editor-in-chief: Wesley Mendes-Da-Silva (Fundação Getulio Vargas, EAESP, Brazil) Paula C. P. de S. Chimenti (Universidade Federal do Rio de Janeiro, COPPEAD, Brazil) Reviewers: Gustavo Nobre (Universidade Federal do Rio de Janeiro, COPPEAD, Brazil) (0) Júlia Monteiro (Universidade Federal do Rio de Janeiro, COPPEAD, Brazil) (6) Peer Review Report: The Peer Review Report is available at this external URL. Received: February 27, 2020 Last version received: October 16, 2020 Accepted: December 07, 2020 


\section{THE AMAZON}

Superlatives are often used when characterizing the Amazon: the greatest biodiversity in any tropical forest on Earth, the largest drainage basin in the world, and the highest concentration of terrestrial species on the planet. It is almost seven million square kilometers spread across seven Brazilian states and five countries in Latin America in addition to Brazil, in which approximately $60 \%$ of the Amazon basin is located. This catchment area contains approximately one fifth of the volume of fresh water on the planet, and on the banks of the Amazon's rivers, four million people live, including indigenous and riverside people and quilombolas.

The exploitation of natural resources in the Amazon can generate substantial benefits, and the concentration of such resources in this vast region attracts both public and private organizations. These organizations are interested in the region's potential for accommodating major developments, such as the construction of hydroelectric power plants, the installation of mining operations, and the establishment of distribution and logistics centers.

On the other hand, actions in the Amazon can have an influence on the rainfall regime in Brazil and other countries in South America. The region is considered fundamental for maintaining the global climate balance.

Major construction works result in considerable socioenvironmental impacts: deforestation, pollution, the displacement of populations, the violation of human rights, changes in ways of life, and extraordinary demands on basic health and education services. These impacts have a significant effect in this vulnerable and underdeveloped region.

For many years, the Amazon has occupied a prominent place on the global environmental agenda. Major world media outlets, such as the The New York Times, The Economist, The Guardian, Le Monde, El Pais and Der Spiegel.

Recently, the situation in the region seems to have worsened. Between August 2019 and July 2020, the INPE (Brazilian Space Research Institute) registered a 34\% increase in deforestation. This makes measures for addressing the roots of the problems that affect the Amazon region even more urgent.

\section{PREVIOUS EXPERIENCES IN THE AMAZON REGION}

The Amazon has been the focus of work by FGVces and IFC for a long time. 'Large-Scale Projects in the Amazon - Lessons Learned and Guidelines' is part of the 'Local Development Program' that is coordinated by Daniela, who has been working for more than 15 years with infrastructure and mining works and with indicators for monitoring local development. The project started in 2015 and follows three other projects that were also undertaken by FGVces in the Amazon.

The first project took place in Juruti, Pará State, a region that was home to a mining plant. In 2006, the North American mining company Alcoa asked FGVces and the Brazilian Biodiversity Fund (Funbio) to draw up a plan that would make sustainable development possible, considering the profound social, economic, and environmental changes that would be experienced with the arrival of this undertaking. The result of this work was the Sustainable Juruti model, following which, in participation with other actors, a tool with development indicators for measuring transformations occurring in the affected location was constructed.

The second project involved the region on the Madeira River in Rondônia State, which received the Jirau hydroelectric plant. In 2008, Energia Sustentável do Brasil (ESBR) asked FGVces to develop a project that would guarantee that the work being undertaken would leave a positive legacy for the region. The ESBR wanted to set up an industrial hub next to the hydroelectric plant. In 2009, FGVces carried out a diagnosis and prepared a regional development plan, in which it pointed out the opportunities for forest economics and certified wood. The plan did not materialize, but ESBR tried to take the proposal on board and assumed long-term commitments.

The third project was for the region in which the Belo Monte hydroelectric plant was built in Pará. The plant is one of the largest hydroelectric projects in the world and represents the culmination of a series of controversies involving large undertakings in the Amazon and local societies. In this project, FGVces developed a tool for monitoring the conditions that were established by the environmental license.

In assessing all these experiences, Daniela and her colleagues concluded that "Considering local social demands, there was a great disconnect between project plans and their implementation ... it was also clear that there were no mechanisms for consolidating good practices and the lessons learned with regard to how to manage local development." In other words, in addition to the fact that few practices were adopted or lessons learned - if any - they were not systematized for future use.

Daniela and her colleagues also noticed systemic problems, such as the misuse of financial resources, a mismatch between revenue generation and needs, and a lack of clarity with regard to roles and responsibilities. That was the moment when they decided what the next steps of their operation in the region would be like.

Daniela and Hector realized that yet another project focusing on a major project would not be enough to reduce 
the socioenvironmental impacts in the region. They needed to ensure that all construction work started with a plan for mitigating social and environmental damage.

According to Daniela, "We wanted to debate the mistakes that were repeated. So we decided to organize what we knew, gather the knowledge of those involved with the Amazon context, and think of solutions to stop these mistakes from being repeated."

For Hector, "Change was necessary, and we went into this process because we needed to be part of this conversation ... but we realized that there was no articulate conversation about the topic. Official documentation was going backwards and forwards, but there was no robust dialogue that considered everyone involved. We needed to create this dialogue not by trying to reinvent elements that already existed but by incorporating what was already there and organizing everything to create something new."

With this vision in mind, Daniela and her team started the new project, in partnership with the IFC, led by Hector.

\section{'LARGE-SCALE PROJECTS IN THE AMAZON: LESSONS LEARNED AND GUIDELINES'}

FGVces, established in 2003, is one of 18 applied research centers in FGV's São Paulo School of Business Administration. The center develops public and corporate management strategies and policies and tools for sustainability at the local, national, and international levels. At the beginning of 2017, it had over 60 researchers and approximately 80 partner organizations, including private companies, social organizations, foundations, institutes, public departments, and universities.

The IFC, in turn, was created in 1956 and is part of the World Bank, one of the largest sources of funding for developing countries. The IFC operates in more than 100 developing countries, where it supports the private sector in combating poverty and seeking prosperity. The organization provides assistance through financial products, such as participation in corporate equity, long-term loans, and advisory services. Brazil has received a representative portion of the IFC's investments.

In seeking solutions to the negative impacts caused by large developments, FGVces and IFC conceived the project 'Large-Scale Projects in the Amazon - Lessons Learned and Guidelines.' Daniela, the project coordinator at FGVces, relied on her previous experience in the region to define the scope of the project. She and her team identified two objectives: avoiding the negative socioenvironmental impacts of major construction work in the region and creating a guide for best practices to reduce such impacts.
To address the complexity of the project, various social technology practices were used. According to Daniela, "The central issues of the project were divided into six lines of action, each with its own responsible working group." The six lines of action that were defined were: (1) territorial and land-use planning; (2) institutional capabilities; (3) financial instruments; (4) the human rights of indigenous peoples, traditional communities, and quilombolas; (5) the human rights of children, adolescents, and women; and (6) the authorized removal of vegetation.

The activities of the working groups began in October 2015 and lasted for 18 months. According to Daniela, "To facilitate the exchange of experiences and information in the extensive network of actors who were involved, each group arranged events within the scope of its own theme. More than 180 organizations and 480 people took part in the work with us."

One of the challenges faced by the team was to design a new methodology that had greater scope and was different from what had been used in previous projects. For Daniela, "We had in mind that it was no longer a question of proposing diagnoses and solutions for a location where there was going to be a development. The work aimed at mapping out impacts on the social, environmental, and economic dimensions from the perspective of multiple social actor, and managing the demands and voices of different stakeholders that were often conflicting - and still engaging them, with the aim of organizing the lessons learned and coming up with recommendations in both the public and private spheres."

Considering this broad and challenging scope, four stages were planned. The 'first stage' - the systematization of knowledge - sought to organize the accumulated knowledge regarding each of the six working group topics. To do this, two prior consultation meetings were held with approximately 40 participants, in addition to bibliographic research and more than 60 interviews. The prior consultation exercise proved the importance of creating guidelines for major projects in the Amazon. Consolidation of the discussions generated more than 40 publications and reports, which are available on the website of the initiative. These reports and documents were used to support subsequent activities.

The 'second stage' — articulation and discussion aimed to link the actors involved and discuss controversial aspects in an attempt to identify points of convergence and facilitate alignment. The six thematic groups interacted with participants from the business, public, financial, academic, and civil society sectors. Depending on the interaction necessary for understanding each topic, the working groups selected different activity formats - meetings, consultation seminars, theme seminars, and participatory seminars - as well as different geographical locations. In all, 18 meetings and 5 seminars were organized in Altamira, Belém, Brasília, 
and São Paulo. The premise of broad and diverse participation encouraged the team to involve indigenous, quilombola, and traditional people in all working groups. This was crucial for subsequently disseminating the content that was discussed.

The 'third stage' - formulation of the guidelines focused on developing the guidelines for future developments. The content that was created was the result of the research and the discussions that were led by the leaders of the six working groups. In addition to the preliminary drafting of the guidelines, common (transversal) priorities were identified between the working groups that were related to focal issues, such as strengthening cooperation between social actors, avoiding resource waste, guaranteeing the rights of vulnerable groups, and ensuring knowledge and information transparency. FGVces and IFC also conducted a public consultation, the aim being to collect additional contributions relating to the guidelines that had been formulated and that were made available on the initiative's website (http://diretrizes-grandesobras.gvces.com.br/ retrieved on December 15, 2020), alongside all the content that had been prepared in the previous phases. A total of 45 contributions were received, which led to 14 changes to the guidelines.

The 'fourth stage' - dissemination and engagement - involved activities aimed at communicating the work that had been done and consolidating the social actors' engagement with the guidelines, the aim being to facilitate their effective implementation. FGVces and IFC shared their reports on the evolution of activities and the results of the initiative. Events were planned in multiple locations to ensure that participation was both broad and diverse.

\section{LAUNCHING THE GUIDELINES}

The guidelines were launched at an event in Belém for representatives of the various stakeholders who took part in the project, such as Alcoa, Votorantim, Vale, Caixa Econômica Federal, the Coordinating Office of Indigenous Organizations of the Brazilian Amazon (Coiab), the State Coordinating Office of Associations of the Remaining Quilombo Communities in Pará, Funbio, the Federal University of Pará, and dozens of organizations from the private, public, and third sectors.

Daniela, Hector and the teams presented the path they had taken and the activities that had made it possible to prepare the 25 guidelines (Appendix 1). Daniela explained to the assembled audience: "We can already see the benefits the guidelines are generating. With a lot of participation at all stages, the project enabled stakeholders - who often had different positions - to interact in a neutral and cooperative environment, far from the pressures of a specific undertaking. The guidelines, reports, and other products that were generated reflect points of convergence between these multiple actors, which is very important for the implementation cycle, which is the next step we'll be taking."

Daniela also pointed out that "implementation of the guidelines will bring benefits from various sides. From the business point of view, we see that adopting the guidelines can help increase predictability and reduce risks, which are critical factors when it comes to implementing major developments. In terms of social benefits, on the other hand, adopting the guidelines can help protect and develop populations, especially indigenous people, quilombolas, and riverside dwellers. Lastly, but no less important in terms of environmental benefits, adopting the guidelines can help improve the shared management of natural resources, which is something that's really necessary in the Amazon region."

Daniela closed the event by stressing yet again the challenge ahead: introducing the guidelines. She told the audience that "we need to continue relying on the participation of everyone so that drafting the guidelines comes off the drawing board and becomes a reality." At the end of the event, some companies offered to carry out pilot projects for applying the guidelines, and the debate continued on the best way to start this new phase.

\section{NEXT STEPS}

Back home, Daniela and Hector reflect on the new cycle that will begin in the project, which will include applying the guidelines in new undertakings in the Amazon. The main challenge will be to guarantee feasible changes when realizing these undertakings: changes that make it possible to disseminate in practice the knowledge that was generated in the previous cycle, thus linking the various agents and boosting the application of the guidelines.

In addition to implementing the guidelines in Brazil, the project intends to expand its operations to other countries in the Amazon region. To this end, contacts were made in Peru and Colombia.

Introducing the guidelines in Brazil and expanding the model to include other countries in the Amazon territory are challenges that will require considerable effort. It will be a time to understand the extent to which the actors involved in drafting the guidelines are, in fact, willing to adapt and change to avoid the negative socioenvironmental impacts of major construction work in the Amazon region. Daniela and Hector remain confident that the lessons learned and the engagement they have secured are the basis they will need, but they are trying to identify what else might contribute toward ensuring the continued success of this initiative. 


\section{APPENDIX 1}

Table A1. Guidelines for large-scale projects in the Amazon.

\section{Territorial and land-use} planning

Financial instruments

(1) The territory must be understood as a strategic element of regional planning that supports decision-making and the formulation and execution of major construction works in the Amazon.

(2) Territorial planning processes must have mechanisms and procedures aimed at convergence, increased capabilities, adequate financing and effective monitoring.

(3) Land-use planning is essential for development and for proper planning; therefore, it must be carried out before the installation of major works in the impacted territories.

(4) Establishing governance with full social participation is essential to planning and territorial development processes.

(5) Financial that are collectively can respond to their instruments must meet and respond to the local development agendas constructed for the territories.

(6) Financial instruments must be supported by the participatory and representative governance arrangements and spaces of the different actors involved.

\section{(7) Financial} instruments must be flexible, dynamic, and structured in such a way as to consider the demands of the different implementation phases of major works.

(8) Financial instruments must have strategies for investing resources that mission and objectives, taking into account the different specificities of the demands and the investors, in order to invest efficiently and effectively.

(9) Financial instruments must have a system for monitoring their processes and results concerning the effectiveness of the investments in achieving their objectives.
Indigenous people, Institutional capabilities traditional communities, and quilombolas

(10) The diagnosis of demands and the planning of institutional strengthening initiatives must be accurate and inclusive and have sufficient funds to be properly carried out.

(11) The strengthening of institutional capabilities must balance tangible and intangible factors.

(12) Strengthening capabilities should include all the actors involved, recognize asymmetries, and foster dialogue.

(13) The social participation routines of territorial governance arrangements are the priority for helping support the institutional positions that are relevant to capabilitybuilding processes. with indigenous peoples,
(14) Territorial planning and development processes must be established with specific public policies and protective measures to promote the social well-being of indigenous peoples, traditional communities, and quilombolas.

(15) Efforts and investments must be linked to improve the efficiency and effectiveness of environmental licensing, with proper consideration of the components related to indigenous peoples, traditional communities, and quilombolas.

(16) Investments must be made in improving communication and governance processes traditional communities, and quilombolas, using appropriate channels, formats, language, and motivations to ensure strengthened participation in the planning process and throughout the useful life of the undertakings.

(17) The effectiveness of prior consultation with indigenous peoples, traditional communities, and quilombolas must be ensured in a broad and comprehensive manner, including during planning processes.
Children, adolescents, and women

(18) It is essential to carry out a Human Rights Impact Assessment study when planning major works, as well as during the installation and operation phases, as a measure for correctly identifying the vulnerabilities and risks for guiding the preventive and control actions employed by the state and by companies.

(19) Priority should be given to the planning, installation, and continued operation of specific social equipment that includes children, adolescents, and women and that can guarantee them access to essential rights and services.

(20) Corporate management of the impacts of large enterprises must prioritize the prevention, control, and monitoring of risks to human rights, using listening mechanisms and indicators that can assess the quality of the measures adopted.

(21) The continuous participation of local civil society must be ensured, with children, adolescents, and women taking a leadership role in areas in which decisions are made with regard to major enterprises, and spaces for the greater mobilization of these segments and specific sectoral councils must be valued.
Authorized removal of vegetation $\left(^{*}\right)$

(22) The introduction of operational procedures for the authorized removal of vegetation must be supported by normative guidance under the administrative procedures of the public sphere, focusing on the use and disposal of the wood and the woody material removed.

(23) Actions related to the authorized removal of vegetation must be planned, with a focus on the use and disposal of the material removed and with the support of studies, diagnoses, and guidelines.

(24) The full use of forest materials from the authorized removal of vegetation must prioritize disposal that is guided by strengthening regional forest chains and boosting local economies.

(25) Participation and social control in the decisions taken and in the follow up on the disposal of the materials coming from the authorized removal of vegetation increase the effectiveness of the actions and minimize socioenvironmental costs.

Note. ${ }^{*}$ This topic emerged as an offshoot of reflections on environmental and territorial management, generating one-off guidelines from a specific working group. Source: Adapted from: Ang, H. G, \& Monzoni, M. (2017). Grandes obras na Amazônia: Aprendizados e diretrizes. São Paulo: FGVces \& IFC. Retrieved from https://bibliotecadigital.fgv.br/dspace/handle/10438/18320. 


\section{ABSTRACT}

This teaching case is intended for use in undergraduate and graduate courses in public administration and business administration, in subjects that deal with the theme of sustainability. The following topics can be worked on: the triple bottom line, sustainable development, stakeholder management, and engagement of social actors. The case narrates how FGVces (Center for Sustainability Studies, from FGV Eaesp) and IFC (International Finance Corporation, from the World Bank) carried out a project aimed at the sustainable development of the Amazon. The result was the creation of 25 guidelines for the execution of large projects in the region. The case focuses on the end of the first phase, at which point the project leaders reflect on the path taken and the challenge for implementing the guidelines. Its discussion allows students to immerse themselves in dilemmas related to sustainable development, discuss the dilemmas and challenges related to conducting a project that involves multiple stakeholders, and reflect on the best form of implementation. The objective is for the students to incorporate the premise of sustainable development in their decisions, to be able to identify the dilemmas inherent to the materialization of this concept, and to weigh the pros and cons of different pathways.

Keywords: sustainable development; Amazon; engagement of social actors; stakeholders' management.

\section{EDUCATIONAL AIMS}

This case was developed to provide a structured discussion on how the concept of sustainable development can manifest itself in practice. The case allows students to: first, recognize the three pillars (economic, social, and environmental) of sustainable development; second, critically analyze the trade-offs between economic benefits and socioenvironmental benefits; third, recognize the need to engage social actors that have conflicting interests to promote a balance between economic and socioenvironmental benefits; and fourth, discuss alternatives for managing stakeholders, considering their particular economic, social, and environmental demands.

\section{CENTRAL THEMES}

This case enables three central themes to be addressed: (a) the triple bottom line; (b) stakeholder management; and (c) engaging social actors.

\section{RESUMO}

Este caso de ensino destina-se ao uso em cursos de graduação e pósgraduação de administraçáo pública e administração de empresas, em disciplinas que tratem do tema sustentabilidade. Podem ser trabalhados os seguintes tópicos: desenvolvimento sustentável, tripé da sustentabilidade, gestão de partes interessadas e engajamento de atores sociais. $\mathrm{O}$ caso narra como o FGVces (Centro de Estudos de Sustentabilidade, da FGV Eaesp) e a IFC (International Finance Corporation, do Banco Mundial) realizaram um projeto voltado para o desenvolvimento sustentável da Amazônia. O resultado foi a criação de 25 diretrizes para a realização de grandes obras na regiâo. $\mathrm{O}$ caso foca o término da primeira fase, momento no qual os líderes do projeto refletem sobre o caminho percorrido e o desafio para implementação das diretrizes. Sua discussão permite aos estudantes imergir nos dilemas relacionados ao desenvolvimento sustentável, discutir os desafios relacionados à condução de um projeto que envolve múltiplas partes interessadas, e refletir sobre a melhor forma de implantação. $\mathrm{O}$ objetivo é que os estudantes incorporem a premissa de desenvolvimento sustentável às suas decisóes, e que sejam capazes de identificar os dilemas inerentes à materialização deste conceito e de analisar prós e contras de diferentes caminhos.

Palavras-chave: desenvolvimento sustentável; Amazônia; engajamento de atores sociais; gestão de partes interessadas.

\section{TARGET AUDIENCE}

Sustainability is a mainstream subject of increasing importance given the economic, social, and environmental challenges the world is facing. This case can be used in undergraduate and graduate courses in public administration. With certain adaptations, it can also be used in undergraduate and graduate courses in business administration. Here are examples of the disciplines with which the case can be used: (a) sustainability; (b) socioenvironmental management; (c) corporate social responsibility; (d) project management; (e) public policy.

\section{PREPARING THE STUDENTS}

The case can be applied to discuss the three central themes mentioned above. The teacher can use the case to encourage debate but focus more on one of the themes if time is limited. It is recommended, however, that the three themes be addressed together. 
To facilitate the initial discussion that focuses on the triple bottom line, the teacher can contextualize the concept of sustainable development for the students. The teacher can also encourage students to reflect on the trade-offs between the pillars of the triple bottom line: economic, social, and environmental.

The case shows how a new development can provide the country, large companies, and the community with economic benefits in the form of jobs and stimuli for the local economy. A new development can also have a negative impact on the environment because of the increase in deforestation and on society because of the displacement of populations and the loss of local culture. The guidelines formulated by the project seek to mitigate negative socioenvironmental impacts and democratize economic benefits.

To increase knowledge of the topics dealt with here and encourage discussion, the following texts can be used for support: (a) 'Our Common Future,' the report by the Brundtland Commission that provides a widely accepted definition of sustainable development (Brundtland, 1987); (b) the article 'Partnerships from cannibals with forks: The triple bottom line of 21st-century business,' by Elkington (1998), the author responsible for coining the term the triple bottom line (TBL); (c) the UN document 'Sustainable Development Goals (SDG)' (United Nations [UN], 2020).

The debate about stakeholder management and engaging social actors can be based on the challenges faced by those involved in the transition between the experiences of previous projects in the Amazon region and the decision to create the new project and can focus on developing the guidelines.

When the decision was made to carry out a broader project, Daniela and Hector were faced with the need to manage a large group of stakeholders with great diversity and many conflicts. The social technology adopted in the project was aimed at facing up to the complexity of the challenge they were tackling.

To facilitate discussion on this topic, the following support materials can be used: (a) 'A stakeholder approach to strategic management,' by Freeman and McVea (2001). This text introduces the concept of managing stakeholder groups; and (b) 'Toward a theory of stakeholder identification and salience: Defining the principle of who and what really counts,' by Mitchell, Agle and Wood (1997). This text provides guidance on identifying and classifying stakeholder groups.

As complementary reading material, the teacher can also indicate the complete report on the project 'Large-Scale Projects in the Amazon - Lessons Learned and Guidelines,' by Ang and Monzoni (2017). Reading it will help students become familiar with the content of the guidelines and the way they were prepared.

\section{SUGGESTED QUESTIONS FOR STUDENTS}

At the beginning of the session, the teacher can seek a connection with the case based on 'immersion questions' 1 and 2 .

1. What positive and negative impacts are generated in the Amazon region as a result of the establishment of major developments?

2. Which stakeholder groups may be affected by major developments in the Amazon region?

The teacher can then use 'transition questions', the aim being to encourage students to reflect on project development and the associated dilemmas:

3. Which main factors led to the development of the 'LargeScale Projects in the Amazon - Lessons Learned and Guidelines' project?

4. What were the main challenges faced when preparing the guidelines? How were they dealt with?

Finally, the teacher can indicate two 'defining questions' about implementing the guidelines and facing up to the main dilemmas in the case:

5. How can the effective application of the guidelines be boosted?

6. What should be the focus of action after divulging the guidelines: promoting their application in Brazil or disseminating them in other countries in the Amazon region?

\section{TEACHING PLAN}

At the beginning of the class, the teacher should encourage an inductive learning process in the classroom and try to engage the students with the topic. Discussion can begin with some general questions that allow the students to establish a connection with the theme, followed by other questions that allow the fundamental concepts guiding the analysis of the case to be briefly revisited:

(a) What do you understand by sustainable development?

(b) Do you think the subject has become a mere cliché, or is it finally being taken seriously?

(c) What is the triple bottom line?

(d) What does managing stakeholders mean?

(e) How are these concepts related to this case? 
The following references can provide the teacher with support: Elkington (1998) and Freeman and McVea (2001).

After this opening session, the teacher should help the students understand the social and economic contexts surrounding major developments in the Amazon. The teacher should then explore specific issues related to the first phase of the project and, finally, encourage reflection on the essential definitions relating to introducing the guidelines.

\section{What positive and negative impacts are generated in the Amazon region as a result of the establishment of major undertakings?}

This question is direct and allows the impacts of large undertakings to be explored. Students should be able to identify these possible impacts. The teacher can help them classify each one according to the triple bottom line.
A suggestion of the impacts, both positive and negative, and their respective classifications can be seen in the framework plan below (Table 1).

To stimulate debate, the teacher can divide students into two groups, each defending different positions. The first group, based on preservation, argues that natural resources must be preserved intact. The second, based on conservation, seeks to combine economic development and sustainability. This second position is closer to the dominant definition of sustainable development that is found in the UN's Sustainable Development Goals (SDGs).

To facilitate treatment of this issue, the teacher can use the concepts of sustainable development and the triple bottom line, based on the following references: Ambec and Lanoie (2008), Broman and Robèrt (2017), Brundtland (1987) and Elkington (1998).

Table 1. Framework plan 1.

\begin{tabular}{|c|c|c|c|c|c|}
\hline \multicolumn{2}{|c|}{ Economic impacts } & \multicolumn{2}{|c|}{ Social impacts } & \multicolumn{2}{|c|}{ Environmental impacts } \\
\hline Positive & Negative & Positive & Negative & Positive & Negative \\
\hline $\begin{array}{l}\text { Increase in local } \\
\text { income }\end{array}$ & $\begin{array}{l}\text { Income dependent on } \\
\text { the undertaking }\end{array}$ & Generation of jobs & $\begin{array}{l}\text { Relocation of the } \\
\text { population }\end{array}$ & $\begin{array}{l}\text { Removal of vegetation } \\
\text { is authorized and } \\
\text { controlled }\end{array}$ & $\begin{array}{l}\text { Deforestation and } \\
\text { pollution }\end{array}$ \\
\hline
\end{tabular}

\section{Which stakeholder groups may be affected by major developments in the} Amazon region?

This question allows the teacher to introduce the interest group concept and discuss how interest groups can influence or condition the decisions that affect them.

Students should be able to point out the main stakeholders in the case: the different population groups, local associations and NGOs involved with preserving fauna and flora, companies, and government organizations.
The teacher can also encourage students to identify the goals of some of the interest groups and, based on this information, build a scheme according to the following framework plan (Table 2).

The teacher can also encourage students to locate the main points of conflict between interest groups. The discussion can then move on to issues that are more directly related to the project.

To facilitate the treatment of this issue, the teacher can rely on the concept of stakeholder management based on the following references: Freeman (2009); Freeman and McVea (2001), Mitchell et al. (1997).

Table 2. Framework plan 2.

\begin{tabular}{ll}
\hline \multicolumn{1}{c}{ Stakeholders } \\
\hline $\begin{array}{l}\text { Engineering and construction companies } \\
\text { Environmental protection associations }\end{array}$ & $\begin{array}{l}\text { To reduce risks to business and the interruption of construction work } \\
\text { To mitigate the environmental impact and guarantee the long life of the } \\
\text { measures }\end{array}$ \\
$\begin{array}{l}\text { Riverbank communities } \\
\text { Indigenous people }\end{array}$ & $\begin{array}{l}\text { To ensure that any economic benefit is sustainable } \\
\text { To preserve territory, culture, and way of life }\end{array}$ \\
\hline
\end{tabular}




\section{What were the main factors that led to the development of the 'Large-Scale Projects in the Amazon - Lessons Learned and Guidelines' project?}

Discussion of this issue allows the FGVces and IFC initiative to be understood in the context identified and as discussed in the previous questions.

Students should be able to demonstrate their understanding of the environment surrounding the project and identify the factors that led to its development, according to the framework plan below (Table 3).

The teacher must promote the understanding that FGVces and IFC acted as facilitators of a highly complex economic and social process, which was partially blocked by deficient communication between social actors.

In dealing with this issue, the teacher can rely on the main project document: Ang and Monzoni (2017).

Table 3. Framework plan 3.

Factors that led to the development of the project

The region's high potential because of its abundantly rich water and mineral resources

The discrepancy between the region's potential and its economic and human development indicators

A history of the negative impact on local populations associated with large developments in the region

The development goals of the Brazilian federal and state governments and the multiple government organizations present in the region

The objectives of the engineering and construction companies, mining companies, and economic groups interested in investing in the region

The goals and experience of FGVces and the IFC in the region

\section{What were the main challenges faced when preparing the guidelines? How were they dealt with?}

This question makes it possible to address two challenges that were faced by initiatives involving the multiple interest groups that had potentially conflicting focuses. Students should be able to identify the main challenges and describe how they were dealt with by the working team.

The case makes it possible to identify two major challenges and their respective solutions, according to the chart below (Table 4).
The teacher should encourage students to realize that the working team needs to be highly sensitive socially and to be able to facilitate productive interaction between groups that have diverse and often conflicting interests.

The teacher should also encourage students to realize the importance of creating a neutral and cooperative environment that is facilitated by agents that are considered competent and legitimate (FGVces and IFC) for the work to develop.

To facilitate dealing with this issue, the teacher can rely on the main project document: Ang and Monzoni (2017).

Table 4. Plan of chart 4.

\section{Challenges}

How to address a complex situation, involving multiple dimensions and diverse stakeholders

How to align the interests of multiple groups with different origins, visions, and ideologies
Solutions

The FGVces and IFC team employed principles of social technology that led to the creation of six lines of action, which defined the working groups and guided the development of the project

The FGVces and IFC team used social technology practices, involving the intense participation the interest groups, information transparency, and different interaction formats, which included meetings and seminars 


\section{How can application of the guidelines be made more effective?}

As shown in the treatment of the previous question, FGVces and IFC relied on the collaboration and engagement of the social actors through the use of social technology (different types of seminars, public consultations, the sharing of studies and reports, and the publication of reports in different formats).

However, this is not the only possible approach to the problem. Both organizations, for example, could have employed their advocacy efforts in encouraging institutional changes that would have more strictly regulated productive investments in the Amazon region.
The teacher can, for example, create two groups and encourage them to defend two positions, one aligned with the option adopted by FGVces and IFC and the other prioritizing advocacy efforts with decision-makers and regulators. The following framework (Table 5) can be used to facilitate comparison.

After the debate, the teacher can sum up by explaining that the two alternatives are not necessarily mutually exclusive, and a combination/composition of the two could have been adopted.

To facilitate dealing with this issue, the teacher can rely on the concept of stakeholder management based on the following references: Freeman (2009), Freeman and McVea (2001), Mitchell et al. (1997).

Table 5. Framework plan 5.

\begin{tabular}{|c|c|c|c|}
\hline \multicolumn{2}{|c|}{ Engaging social actors } & \multicolumn{2}{|c|}{ Advocacy with the regulators } \\
\hline Advantages & Disadvantages & Advantages & Disadvantages \\
\hline $\begin{array}{l}\text { Engagement generates a product } \\
\text { that represents all the social actors } \\
\text { involved }\end{array}$ & $\begin{array}{l}\text { The end product may be subject to } \\
\text { the influence of power asymmetries }\end{array}$ & \multirow{2}{*}{$\begin{array}{l}\text { Regulatory changes may have } \\
\text { the force of law, obliging all } \\
\text { stakeholders to act accordingly }\end{array}$} & \multirow{2}{*}{$\begin{array}{l}\text { The regulatory framework may } \\
\text { not be effectively applied due to } \\
\text { nonadherence by stakeholders or } \\
\text { monitoring and control difficulties }\end{array}$} \\
\hline $\begin{array}{l}\text { Mobilization generates parallel } \\
\text { gains, such as reducing conflicts } \\
\text { between stakeholders }\end{array}$ & $\begin{array}{l}\text { Stakeholder changes can } \\
\text { affect medium- and long-term } \\
\text { commitments }\end{array}$ & & \\
\hline
\end{tabular}

\section{What should be the focus of action after divulging the guidelines: promoting their application in Brazil or disseminating them in other countries in the Amazon region?}

This final question deals with a crucial aspect of this case and is found in many others: how to move from planning to execution - in other words, how to ensure that what was planned is well executed and achieves the expected objectives.
The case ends precisely with the launch of the guidelines, a moment marked by great hopes and expectations. However, it is also marked by points that need attention. It is suspected, for example, that its scope/reach hinders its absorption and use, particularly by companies and government agencies.

The teacher should encourage students to identify the barriers and the risks and to introduce and develop strategies for addressing them. The following framework (Table 6) can be used to facilitate analysis.

Table 6. Framework plan 6.

\begin{tabular}{ll}
\hline \multicolumn{1}{c}{ Barriers and risks } & \multicolumn{1}{c}{ Strategies for facing them } \\
\hline The entry of new organizations to the region & $\begin{array}{l}\text { Create an association that involves all stakeholders, whose focus is on } \\
\text { attracting and aligning new organizations that may appear } \\
\text { Changes in the constitution of the stakeholders }\end{array}$ \\
$\begin{array}{l}\text { Encourage stakeholders to institutionalize the guidelines in the form of rules } \\
\text { and practices }\end{array}$ & $\begin{array}{l}\text { Carry out a continuous movement of influence over the various spheres of } \\
\text { public power, with the aim of maintaining the basic principles that support } \\
\text { the guidelines }\end{array}$ \\
\hline
\end{tabular}


The teacher should also encourage students to identify the advantages and disadvantages of expanding the project to include other countries in the Amazon region. Is such an initiative capable of helping consolidate the effort that started in Brazil, or will it result in a dispersion of the efforts that should focus on implementing the guidelines in Brazil? The following framework plan (Table 7) can be used to evaluate both paths.
After the debate, the teacher can sum up by mentioning that, once again, the two alternatives are not necessarily mutually exclusive, and a combination/composition of the two could be adopted.

At the end, the teacher can provide a summary of the case by reviewing everything from the contextual aspects to the question of introducing the guidelines. The teacher and students, together, can also register the main lessons learned, relating each to the themes of the case: the triple bottom line, stakeholder management, and engaging social actors.

Table 7. Framework plan 7.

\begin{tabular}{llll}
\hline \multicolumn{1}{c}{ Introduction of the guidelines in Brazil } & \multicolumn{1}{c}{ Disadvantage } & Transposition of the guidelines to other countries \\
\hline \multicolumn{1}{c}{ Advantage } & \multicolumn{1}{c}{ Advantage } & \multicolumn{1}{c}{ Disadvantage } \\
$\begin{array}{l}\text { Maximizes potential efforts, given } \\
\text { the history, the relationships already } \\
\text { established, and the knowledge of } \\
\text { the Brazilian context }\end{array}$ & $\begin{array}{l}\text { The project's positive impact is } \\
\text { restricted only to the Brazilian } \\
\text { Amazon region }\end{array}$ & $\begin{array}{l}\text { The risk of facing difficulties, or } \\
\text { of the project to the entire Amazon } \\
\text { region }\end{array}$ & $\begin{array}{l}\text { of even failing, due to limited } \\
\text { knowledge of the context and the } \\
\text { stakeholders working in other } \\
\text { countries }\end{array}$ \\
\hline
\end{tabular}

\section{WHAT HAPPENS NEXT}

To close the session, the teacher can mention some of the outcomes of the case. Approximately three years after launching the guidelines, Daniela stated that three new initiatives had been carried out, which were a consequence of the project: first, a review of the territorial governance model in a hydroelectric plant that had already been installed in the Amazon; second, the establishment of a public policy laboratory for the region; and third, a sustainable development project associated with paving a highway.
In addition to these initiatives, Daniela mentioned the application of the guidelines to a project for installing a mining company in Peru. These four initiatives are evidence that the guidelines are being adopted and proof of the positive impacts that the social technology that was used is having. In her statement, however, Daniela highlighted one of the essential challenges facing the region: balancing the reasonable expectations its people have of improving their material conditions and quality of life without damaging the environment and compromising the future of generations to come. 
Table 8. Lesson time plan.

\begin{tabular}{l}
$\begin{array}{l}\text { Time } \\
(\min )\end{array}$ \\
\hline INTRODUCTION \\
$\begin{array}{ll}\text { a. What do you understand by sustainable development? } \\
\text { b. Do you think the subject has become a mere cliché, or is it finally being taken seriously? }\end{array}$ \\
$\begin{array}{ll}\text { c. What is the triple bottom line? } \\
\text { d. What does managing stakeholders mean? }\end{array}$ \\
e. How do these concepts relate to the case?
\end{tabular}

\section{CONTEXT}

Impact analysis

Q1: What positive and negative impacts are generated in the Amazon Region as a result of the setting of major undertakings?

Managing stakeholders

\section{PROJECT DEVELOPMENT}

\section{Drivers}

10 Q3: What were the main factors that led to the development of the 'Large-Scale Projects in the Amazon — Lessons and Guidelines' project?

20 Challenges

Q4: What were the main challenges faced when preparing the guidelines? How were they dealt with?

\section{PROJECT IMPLEMENTATION}

Dilemma 1: basic implementation conditions

Q5: How can the application of the guidelines be made more effective?

20

Dilemma 2: implementation priority

Q6: What should be the focus of action after divulging the guidelines: promoting their application in Brazil or disseminating them in other countries in the Amazon region?

\section{CONCLUSION}

\section{REFERENCES}

Ambec, S., \& Lanoie, P. (2008). Does it pay to be green? A systematic overview. Academy of Management Perspectives, 22(4), 4562. https://doi.org/10.5465/amp.2008.35590353

Ang, H. G., \& Monzoni, M. (2017). Grandes obras na Amazônia: Aprendizados e diretrizes. Sáo Paulo: FGVces \& IFC. Retrieved from https://bibliotecadigital.fgv.br/dspace/handle/10438/18320

Broman, G. I., \& Robèrt, K.-H. (2017). A framework for strategic sustainable development. Journal of Cleaner Production, 140(Part 1), 17-31. https://doi.org/10.1016/j.jclepro.2015.10.121

Brundtland, G. H. (1987). Our common future - Call for action. Environmental Conservation, 14(4), 291-294. https://doi.org/10.1017/S0376892900016805
Elkington, J. (1998). Partnerships from cannibals with forks: The triple bottom line of 21 st-century business. Environmental Quality Management, 8(1), 37-51. https://doi.org/10.1002/tqem.3310080106

Freeman, R. E. (2009) What is Stakeholder Theory? Retrieved from https://www.youtube.com/watch?v=bIRUaLcvPe8

Freeman, R. E., \& McVea, J. (2001). A stakeholder approach to strategic management. Retrieved from http://faculty.wwu. edu/dunnc3/rprnts.stakeholderapproach.pdf

Mitchell, R. K., Agle, B. R., \& Wood, D. J. (1997). Toward a theory of stakeholder identification and salience: Defining the principle of who and what really counts. Academy of Management Review, 22(4), 853-886. https://doi.org/10.5465/amr.1997.9711022105

United Nations (2020). Sustainable Development Goals. Retrieved from http://www.un.org/sustainabledevelopment/ sustainable-development-goals/ 


\section{Authorship}

\section{Thomaz Wood Jr.*}

Fundação Getulio Vargas, Escola de Administração de Empresas de Sáo Paulo (FGV EAESP)

Av. Nove de Julho, no 2029, Bela Vista, 01313 902, São Paulo, SP, Brazil

E-mail address: thomaz.wood@fgv.br

(D) https://orcid.org/0000-0002-5610-4699

\section{Dafne Oliveira Carlos de Morais}

Centro Universitário FEI

Rua Tamandaré, no 688, Liberdade, 01525-000, São Paulo, SP, Brazil

E-mail address: dafne.morais@fei.edu.br

(D) https://orcid.org/0000-0001-9188-7900

* Corresponding Author

\section{Funding}

The authors would like to thank FGV / EAESP Pesquisa for the financial support granted in the Project "Cases of Social Impact" 2017-1.

\section{Conflict of Interests}

The authors have stated that there is no conflict of interest.

\section{Plagiarism Check}

The RAC maintains the practice of submitting all documents approved for publication to the plagiarism check, using specific tools, e.g.: iThenticate.

\section{Authors' Contributions}

$1^{\text {st }}$ author: conceptualization (lead); funding acquisition (lead); methodology (lead); project administration (lead); supervision (lead); writing-original draft (supporting); writing-review \& editing (equal).

$2^{\text {nd }}$ author: data curation (lead); investigation (lead); writingoriginal draft (lead); writing-review \& editing (equal).

\section{Copyrights}

RAC owns the copyright to this content.

\section{Peer Review Method}

This content was evaluated using the double-blind peer review process. The disclosure of the reviewers' information on the first page, as well as the Peer Review Report, is made only after concluding the evaluation process, and with the voluntary consent of the respective reviewers and authors.

\section{Data Availability}

RAC encourages data sharing but, in compliance with ethical principles, it does not demand the disclosure of any means of identifying research subjects, preserving the privacy of research subjects. The practice of open data is to enable the reproducibility of results, and to ensure the unrestricted transparency of the results of the published research, without requiring the identity of research subjects. 